\title{
Pelatihan Pemanfaatan Toko Online Sebagai Media Pemasaran Produk pada UKM Saka Gemilang
}

\author{
${ }^{1}$ I Made Darma Susila, ${ }^{2}$ Muhammad Riza Hilmi, ${ }^{3}$ I Putu Arya Suita Darma \\ Institut Teknologi dan Bisnis STIKOM Bali \\ Email: 1darma_s@stikom-bali.ac.id, ${ }^{2}$ riza@stikom-bali.ac.id, ${ }^{3}$ darmaarya18@yahoo.com
}

\begin{abstract}
ABSTRAK
Industri furniture interior merupakan usaha yang menjadi trend dan dinikmati di kawasan pariwisata khususnya area Bali. Furniture interior mengedepankan kesan kenyamanan, kualitas tampilan yang tinggi, dan diproduksi secara semi otomatis. UKM Saka Gemilang merupakan UKM yang sudah cukup lama berkecimpung dalam produksi furniture interior yaitu sejak tahun 1993. Sejalan dengan usahanya, UKM ini terkadang mengalami penurunan penjualan. Hal ini disebabkan karena proses penjualan yang saat ini dilakukan masih belum optimal, yaitu dilakukan secara door-to-door ke lokasi seperti perkantoran, villa, hotel dan restoran dengan menunjukkan buku list produk. Sehingga dalam hal ini proses produksi dan jumlah produksi dari UKM sangat tergantung dari hasil pemasaran yang saat ini dilakukan. Untuk menangani permasalahan penjualan produk UKM, maka diusulkan kegiatan pelatihan pemanfaatan pelatihan pemanfaatan toko online yaitu OLX dan tokopedia yang digunakan sebagai media pemasaran. Kegiatan ini bertujuan untuk memberikan pelatihan pemanfaatan toko online dengan harapan bahwa penjualan produk dapat meningkat. Evaluasi kegiatan dilakukan dengan cara pengukuran kemampuan mitra dalam menggunakan aplikasi dengan mengikuti sepuluh skenario yang telah ditentukan. Hasil pengukuran sebesar $80 \%$ yang artinya mitra sudah bisa mengoperasikan aplikasi Olx dan tokopedia.
\end{abstract}

Kata kunci : toko online, Furniture interior, pemasaran.

\section{ABSTRACT}

The interior furniture industry is a trendy business and is enjoyed in the tourism area, especially in the Bali area. Interior furniture emphasizes the impression of comfort, highquality display and is produced in a semi automatic. UKM Saka Gemilang is a UKM that has been in the interior furniture production for quite a long time since 1993. In line with its business, this UKM has experienced a decline in sales. This condition caused by the sales process is not optimal, carried out door-to-door to locations such as offices, villas, hotels, and restaurants by showing a product list book. So, in this case, the production process and the amount of production from UKM is very dependent on the marketing results that are currently carried out. To solving the problem, it is suggested that training activities on the utilization of online store utilization training, OLX and Tokopedia, be used as marketing media. Evaluation of activities is done by measuring the ability of partners in using the application by following ten predetermined scenarios. Evaluation of activities is done by measuring the ability of partners in using the application by following ten predetermined scenarios. The measurement results is $80 \%$, which means partners can already operate the Olx and Tokopedia applications.

Key words: online shop, interior furniture, marketing 


\section{PENDAHULUAN}

Funiture merupakan industri yang cukup diminati khususnya di Bali. Furniture merupakan salah satu kelengkapan di industri perhotelan atau penginapan, villa, restoran hingga kelengkapan pada rumah pribadi. Furniture yang digunakan di kawasan perhotelan ataupun restoran merupakan jenis furniture interior yang memiliki kelas tersendiri yang mengedepankan kualitas, dan kenyamanan. Di Bali, seiring dengan berkembangnya sektor pariwisata yaitu perhotelan, restoran dan villa, membawa dampak yang signifikan terhadap tumbuhnya industri lokal furniture interior. Bagi pelaku usaha, hal ini menciptakan daya saing yang sangat kompetitif dan memerlukan teknik pemasaran yang tepat dalam proses pemasaran produknya. Di sebagaian usaha industri furniture teknik pemasaran konvensional, yaitu dengan membawa price list ke hotel atau ke villa dirasa tidak efektif dan menimbulkan cost yang tinggi.

UKM Saka Gemilang merupakan UKM yang dijadikan mitra dalam kegiatan pengabdian masyarakat. UKM Saka Gemilang merupakan usaha yang bergerak di industri furniture jenis interior dan telah memulai usahanya sejak tahun 1993. UKM ini memiliki tempat usaha di Jl. Nakula no 21 Dangin Puri Kauh, Denpasar, Bali dan proses produksi dilakukan di rumah sendiri.

UKM Saka Gemilang memiliki jenis produksi seperti matras, payung stand, bantalan, sofa, basket, safety pool, bean bag, upper lamp dan laundry bag. Dalam proses produksi, UKM mempekerjakan 5 - 7 pekerja dan peralatan yang digunakan dalam proses produksi seperti mesin jahit, komputer yang digunakan untuk design, mesin obras, peralatan pertukanan dan dikerjakan semi mesin. Proses produksi meliputi bagian pemotongan bahan dasar, pendesain, penjahit, pekerja serabutan dalam produksi sofa dan pekerja pengiriman. Bahan produksi didapatkan dari Bali dan khusus untuk produksi payung stand dalam ukuran besar, bahan didatangkan dari Jawa Timur.

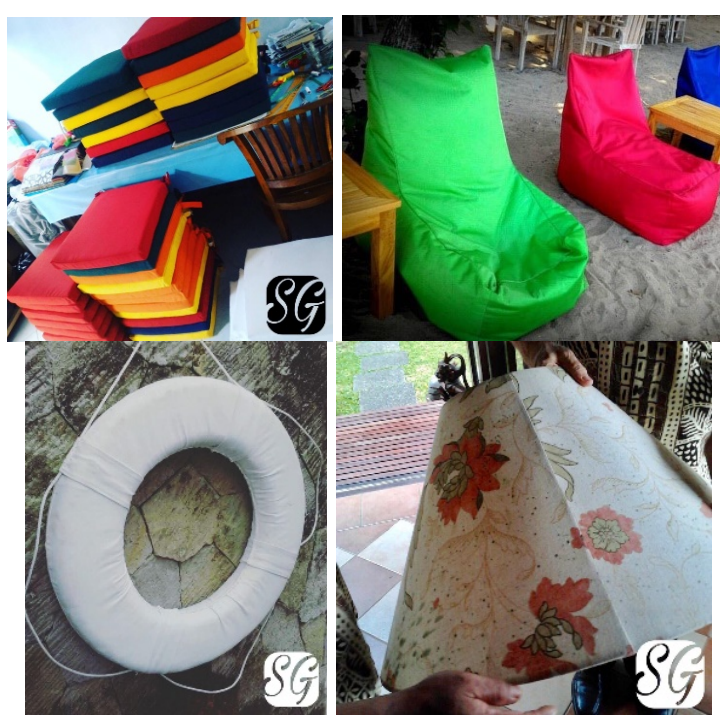

Gambar 1 Produk UKM Saka Gemilang

Untuk proses penjualan, produk matras pool dijual dengan kisaran harga Rp. 750.000 s/d Rp. 1.650.000, payung dengan harga Rp. 1.250.000 s/d 2.500.000, bantalan berkisar Rp. 35.000 s/d 125.000, sofa berkisar Rp. $1.500 .000 \mathrm{~s} / \mathrm{d} \quad \mathrm{Rp}$. 5.000.000, upper lam Rp. 350.000 s/d Rp. 475.000, safety ring pool Rp. $200.000 \mathrm{~s} / \mathrm{d}$ 400.000 dan aneka bag (bean bag, basket laundry bag) berkisar Rp. $150.000 \mathrm{~s} / \mathrm{d}$ 450.000. Selain proses produksi, UKM Saka Gemilang juga bergerak dipenjualan jasa, yaitu menerima service perbaikan dari produk furniture sejenis. Dalam proses produksi, UKM Saka Gemilang mampu memproduksi dalam satu bulan adalah matras pool 20 biji, payung 15 buah, bantalan 25, sofa 1 buah, upper lamp 2030 buah, aneka bag sejumlah $50-150$ buah.

Dalam proses pemasaran, pemiliki usaha melakukan pemasaran secara konvensional yaitu dengan teknik door-todoor, yaitu dengan mendatangi sebuah hotel, villa maupun restoran hingga ke perkantoran. Hal ini dirasa belum efektif dan menimbulkan biaya transportasi. 
Terkait dengan permasalahan pada UKM, maka dilakukan analisis permasalahan dan solusi yang ditunjukkan pada Tabel 1.

Tabel 1. Analisis Situasi

\begin{tabular}{|l|l|l|l|}
\hline No & Bidang & Permasalahan & Solusi \\
\hline 1 & Pemasaran & $\begin{array}{l}\text { - Pemasaran masih } \\
\text { manual dan } \\
\text { konvensional } \\
\text { (door-to-door) } \\
\text { - Pemasaran yg } \\
\text { bersifat } \\
\text { konvensional } \\
\text { menimbulkan } \\
\text { biaya transportasi }\end{array}$ & $\begin{array}{l}\text { Peningkatan } \\
\text { teknik } \\
\text { pemasaran } \\
\text { melalui } \\
\text { pemanfaatan } \\
\text { toko } \text { online. }\end{array}$ \\
\hline 2 & Penjualan & $\begin{array}{l}\text { Pemesanan dan } \\
\text { penjualan melalui } \\
\text { aplikasi chat. }\end{array}$ & $\begin{array}{l}\text { Peningkatan } \\
\text { teknik } \\
\text { penjualan } \\
\text { yang melalui } \\
\text { pemanfaatan } \\
\text { toko } \text { online. }\end{array}$ \\
\hline 3 & $\begin{array}{l}\text { Kompetensi } \\
\text { SDM } \\
\text { (Sumber } \\
\text { Daya } \\
\text { Manusia) }\end{array}$ & $\begin{array}{l}\text { Keterbatasan } \\
\text { pengetahuan SDM } \\
\text { dalam } \\
\text { menggunakan } \\
\text { aplikasi berbasis } \\
\text { teknologi } \\
\text { informasi (toko } \\
\text { online })\end{array}$ & $\begin{array}{l}\text { Pelatihan } \\
\text { pemanfaatan } \\
\text { toko online } \\
\text { sebagai media } \\
\text { pemasaran } \\
\text { dan penjualan } \\
\text { produk UKM. }\end{array}$ \\
\hline
\end{tabular}

\section{RUMUSAN MASALAH}

Permasalahan yang dihadapi oleh Saka Gemilang dalam kegiatan pengabdian masyarakat adalah :

a. Permasalahan pada UKM Saka Gemilang adalah masalah pemasaran dan penjualan. Dimana pemasaran dan penjualan dilakukan masih secara konvensional dan manual, yaitu dengan teknik door-to-door dengan menawarkan buku list produk ke perkantoran, hotel, villa dan restoran. Disisi lain pemesanan produk dan penjualan dilakukan melalui aplikasi chat. Teknik ini dirasa tidak efektif dan menimbulkan biaya baru bagi operasional usaha yaitu masalah biaya transportasi. Plang nama usaha juga tidak terpasang dalam rumah produksi, sehingga produksi hanya dilakukan berdasarkan pemesanan saja.

b. Pekerja dan pemilik usaha sudah mengenal pemanfaatan aplikasi online berbasis chating, namun penggunaan chating adalah sebatas akun personal dan tidak terarsip dengan baik. Pemilik usaha belum memiliki pengetahuan untuk menggunakan toko online.

\section{METODE}

Dalam bisnis diperlukan teknik strategi untuk mengeksploitasi sesuatu yang berbeda (David, 2010). Pemasaran menciptakan hubungan yang menguntungkan (Amstrong G, 2008). Kemajuan teknologi internet dapat mempermudah pemakainya untuk berkomunikasi serta memperoleh informasi yang dibutuhkan dengan cepat dan akurat (Rudy, 2008) (Florentina, 2009). Internet juga yang merevolusi praktek marketing, yang berpotensi menghubungkan antara konsumen dan penjual dengan cara yang belum pernah terjadi sebelumnya (ChaffeyDave, 2009). Untuk meningkatkan service ke konsumen maka diperlukan sebuah perbuatan, upaya atau kinerja (Hoffman, 2006). Untuk meningkatkan service diperlukan sebuah metode yaitu internet marketing yaitu kegiatan marketing dengan bantuan teknologi informasi (Hoffman , 2016) (Strauss, 2009). Dalam bisnis internet marketing memiliki beberapa fungsi yaitu yaitu sebagai sumber komunikasi, sebagai sumber transaksi dan sebagai sumber distribusi (Dehkordi, 2012). Oleh karena itu internet marketing akan dimanfaatkan dalam kegiatan ini dengan pemanfaatan Olx dan Tokopedia.

Metode yang digunakan pada kegiatan pengabdian ini adalah Pelatihan: dimana dilakukan pelatihan penggunaan toko online untuk memasarkan dan menjual produk dari UKM Saka Gemilang. Selain metode pelatihan, pada kegiatan pengabdian yang dilakukan juga menggunakan metode Substitusi Ipteks: dimana kegiatan pengabdian menawarkan ipteks baru yang lebih modern dan efisien daripada ipteks lama. Ipteks yang dimaksud adalah kepemilikan akun toko online, dan mengimplementasikan penggunaannya bagi UKM Saka Gemilang. Melalui toko online, UKM dapat memasarkan, menjual dan 
bertransaksi secara terbuka (online) dengan pembeli tanpa memandang lokasi pembeli, sehingga tidak menambah biaya tranpsortasi dalam hal pemasaran jika dibandingkan denan pemasaran yang bersifat konvensional.

\section{PEMBAHASAN}

A. Alur Pelaksanaan Kegiatan Pengabdian Masyarakat pada UKM Saka Gemilang.

Kegiatan pengabdian masyarakat yang dilakukan, memiliki alur pelaksanaan kegiatan. Adapun alur kegiatan yang dimaksud ditunjukkan pada Gambar 2.

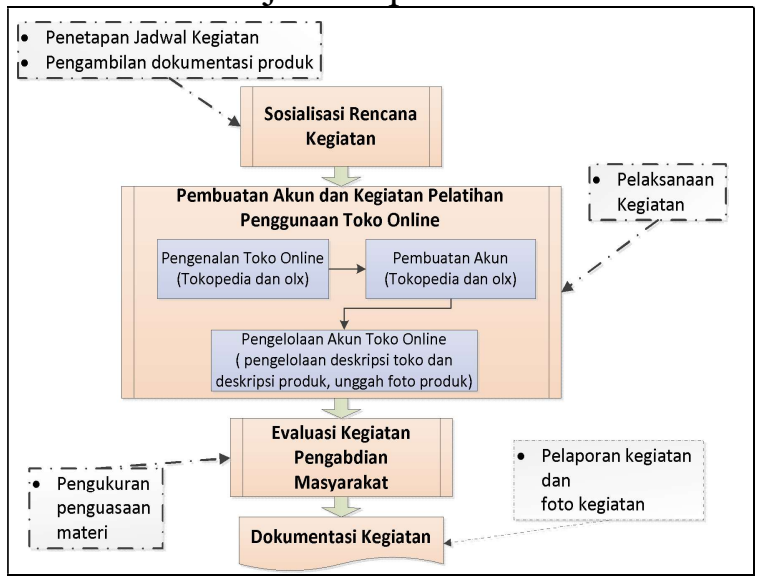

Gambar 2 Alur Pelaksanaan Kegiatan

a. Sosialisasi dan Observasi UKM

Sosialisi rencana kegiatan dilakukan oleh tim pelaksana ke UKM untuk menentukan tanggal dan waktu pelaksanaan serta teknis pelaksanaan kegiatan. Pada saat sosialisasi, disepakati untuk pelaksanaan pada hari Sabtu tanggal 18 Januari 2020 pada pukul 10:00 AM.

b. Kegiatan Pengabdian Masyarakat : Pembuatan Akun dan Kegiatan Pelatihan Penggunaan Toko Online.

Kegiatan pengabdian masyarakat pada UKM Saka Gemilang terdiri dari 3 kegiatan utama yaitu : pengenalan toko online, pembuatan akun dan pengelolaan akun toko online. Pada kegiatan pengenalan toko online, peserta (UKM Saka Gemilang) diberikan informasi mengenai toko online dan pemanfaatannya pada pemasaran secara online. Toko online yang dikenalkan secara adalah Tokopedia dan olx. Pada kegiatan pembuatan akun, UKM Saka Gemilang dibuatkan akun pada toko online Tokopedia dan olx. Akun ini diberikan kepada pengguna dari UKM yaitu pemilik dari UKM Gemilang. Pada kegiatan pengelolaan akun toko online, UKM akan di berikan materi pengelolaan konten toko online. Pengelolaan konten toko online yang dimaksud adalah pengelolaan deskripsi toko (deskripsi UKM Saka Gemilang), deskripsi produk (menjelaskan deskripsi produk yang dihasilkan oleh UKM) dan pengelolaan foto produk (unggah dokumen berupa foto produk dari UKM.

c. Evaluasi Kegiatan

Evaluasi kegiatan dilakukan saat pelaksaan kegiatan pengabdian akan berakhir. Evaluasi dilakukan dengan memberikan kuisioner penilaian kegiatan. Keberhasilan dari kegiatan dengan menilai kemampuan pemilik atau anggota pada UKM untuk mengelola akun toko online. Selain kuisioner kegiatan, kami juga melakukan evaluasi terhadap akun toko online dalam hal riwayat penggunaan sistem. Keberhasilan pencapaian kegiatan adalah UKM mampu untuk menggunakan, mengimplementasikan, dan secara intens melakukan pembaharuan informasi dan mengelola konten dengan baik pada akun toko online.

d. Dokumentasi Kegiatan

Dokumentasi yang dilakukan pada tahap akhir adalah proses pembuatan laporan kegiatan dan foto kegiatan selama kegiatan berlangsung.

B. Jadwal Pelaksanaan Kegiatan

Pelaksanaan kegiatan pengabdian mengacu pada jadwal pelaksanaan yang telah disepakati oleh pelaksana dan UKM Saka Gemilang. Jadwal pelaksanaan kegiatan ditunjukkan pada Tabel 2. 
Tabel 2. Jadwal Pelaksanaan

\begin{tabular}{|c|c|c|c|}
\hline No & Tanggal & Acara & Durasi \\
\hline 1. & $\begin{array}{l}16 \text { Oktober } \\
2019\end{array}$ & $\begin{array}{l}\text { Sosialisasi kegiatan dan } \\
\text { analisa situasi keadaan di } \\
\text { UKM Saka Gemilang }\end{array}$ & 90 Menit \\
\hline 2. & $\begin{array}{l}29 \text { Nopember } \\
2019\end{array}$ & $\begin{array}{l}\text { Sosialisasi kegiatan } \\
\text { pengabdian masyarakat } \\
\text { berupa informasi rencana } \\
\text { kegiatan }\end{array}$ & 60 Menit \\
\hline 3. & $\begin{array}{l}\text { 18 Januari } \\
2020\end{array}$ & $\begin{array}{l}\text { Pelaksanaan Pelatihan } \\
\text { Kegiatan Pengabdian } \\
\text { Masyarakat } \\
\text { - Acara Pembukaan } \\
\text { kegiatan (non formal) } \\
\text { - Pengenalan Toko } \\
\text { Online (olx dan } \\
\text { Tokopedia). } \\
\text { - Pembuatan akun toko } \\
\text { online. } \\
\text { - Pelatihan pengelolaan } \\
\text { konten toko online } \\
\text { - Evaluasi Kegiatan } \\
\text { - Penutupan kegiatan } \\
\text { (non formal) }\end{array}$ & $\begin{array}{l}5 \text { Menit } \\
30 \text { menit } \\
30 \text { menit } \\
100 \text { menit } \\
20 \text { menit } \\
5 \text { menit }\end{array}$ \\
\hline
\end{tabular}

C. Uraian Pelaksanaan Kegiatan

Kegiatan pengabdian masyarakat dilaksanakan pada hari Sabtu tanggal 18 Januari 2020. Pelaksaan pengabdian masyarakat di rumah pemilik UKM Saka Gemilang, dimana yang hadir adalah pemilik UKM, ketua pelaksana kegiatan pengabdian, anggota pelaksana pengabdian dan mahasiswa. Kegiatan yang dilakukan antara lain :

- Acara Pembukaan

Acara pembukaan kegiatan dilakukan secar non-formal yang dibuka oleh ketua pengusul sekaligus ketua pelaksana kegiatan pengabdian masyarakat. Acara pembukaan berlansung 5 menit

- Kegiatan Pelatihan Penggunaan Akun Toko Online

Kegiatan pelatihan dilakukan diawali dengan pengenalan dasar toko online, pemanfaatannya dan beberapa jenis toko online yang umum dikenal oleh masyarakat. Pengenalan toko online yang diberikan adalah toko online Tokopedia dan olx. Pengenalan toko online tokopedia dan olx diberikan kepada UKM saka Gemilang karena mudah digunakan dan sudah sering didengar oleh pemilik UKM. Setelah adanya pengenalan toko online Tokopedia dan olx, peserta kemudia dibuatkan akun toko online. Pembuatan toko online dilakukan bersama peserta dan pelaksana kegiatan. Akun yang dibuat, disinkronisasi ke smartpone pemilik UKM agar setiap notifikasi terkait toko online UKM diberitahukan ke pemilik UKM melalui sistem notifikasi. Setelah pembuatan akun, dilanjutkan dengan pengelolaan konten toko online. Penggunaan toko online diawali dengan pembuatan deskripsi UKM dan legalitas UKM berupa informasi usaha dari UKM.

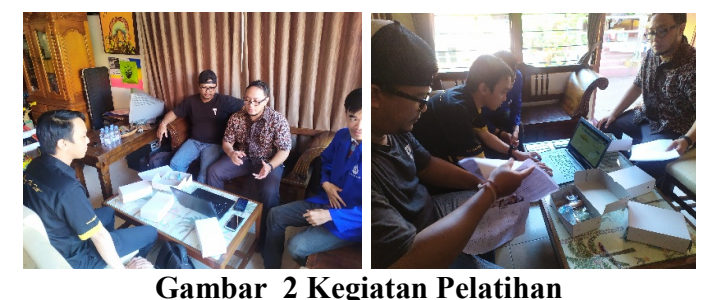

Kemudian dilakukan pembuatan kategori produk dalam bentuk deskripsi produk untuk setiap jenis produk usaha. Setelah itu dilanjutkan dengan mengunggah foto produk sesuai pembuatan deskripsi produk UKM. Pelatihan ini dilakukan selama 160 menit.

- Evaluasi Kegiatan

Evaluasi kegiatan dillakukan selama 20 menit meliputi diskusi dan tanya jawab seputar teknis pengelolaan konten toko online. Pada evaluasi, pelaksana juga mengukur kemampuan dan kecakapan peserta pelatihan dalam menerima materi yang diberikan.

- Acara Penutupan

Acara penutupan diakhiri dengan foto bersama yang diikuti oleh peserta pelatihan (UKM Saka Gemilang) dan Tim pelaksana kegiatan pengabdian masyarakat. 


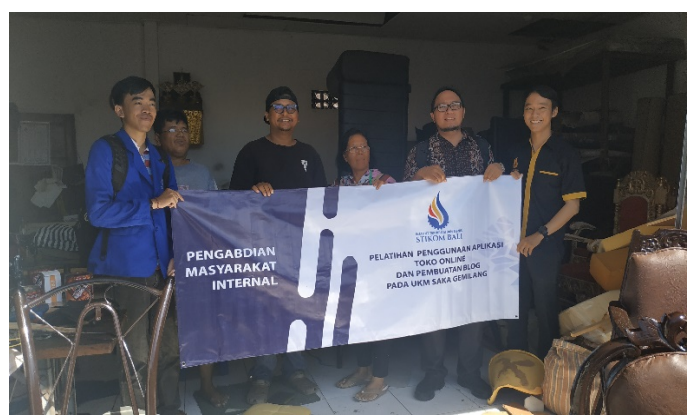

Gambar 3 Penutupan Kegiatan Pengabdian

\section{Akun Toko Online UKM Saka Gemilang}

UKM Saka Gemilang memiliki dua akun toko online, yaitu akun toko online Tokopedia dan akun toko online Olx. Akun toko online Tokopedia ditunjukkan pada Gambar 5.
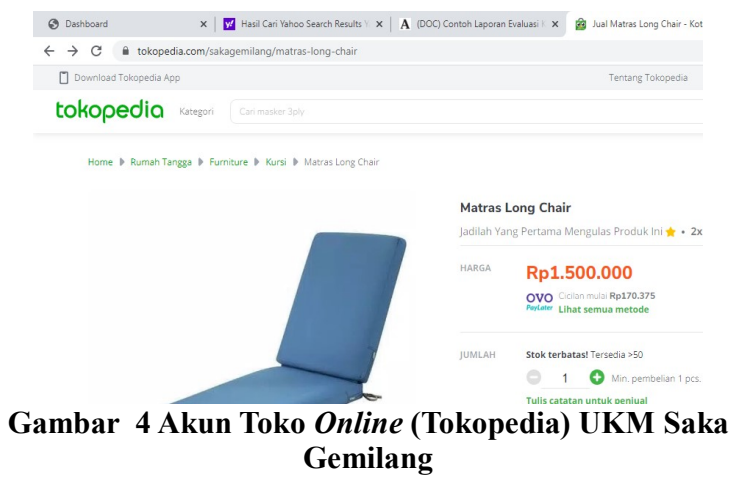

Sedangkan untuk akun toko online Olx dari UKM Saka Gemilang, ditunjukkan pada Gambar 6.

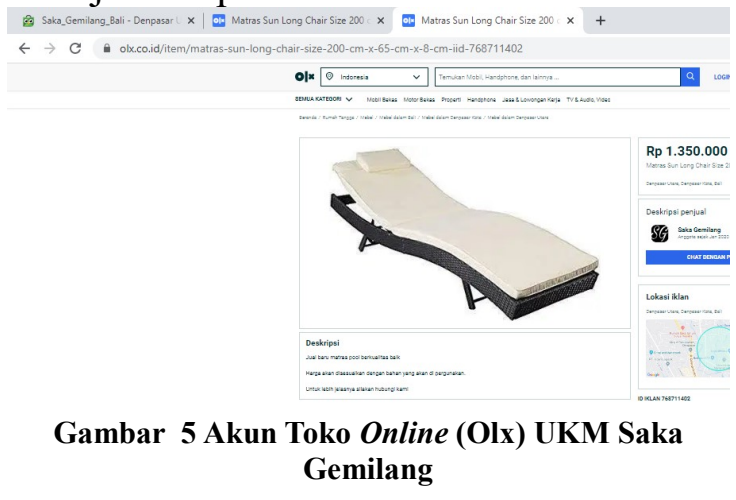

E. Hasil Evaluasi Pelatihan

Hasil evaluasi dilakukan dengan cara melihat kemampuan mitra dalam menggunakan account olx dan tokopedia. Untuk mengukur sejauh mana mitra dalam menguasai, maka dilakukan pengukuran dengan sepuluh skenario yang telah ditentukan. Untuk penentuan nilai dilakukan berdasarkan nilai kualifikasi seperti yang terlihat pada tabel 3 .

Tabel 3. Nilai kualifikasi

\begin{tabular}{|c|l|}
\hline Nilai & \multicolumn{1}{|c|}{ Kualifikasi } \\
\hline 1 & $\begin{array}{l}\text { Sangat Kurang Baik } \\
(\text { SKB) }\end{array}$ \\
\hline 2 & Kurang Baik (KB) \\
\hline 3 & Baik (B) \\
\hline 4 & Sangat Baik (SB) \\
\hline
\end{tabular}

Pada table 4 terlihat dari hasil pengukuran kemampuan mitra dalam menggunakan aplikasi olx dan tokopedia. Hasil kemampuan yang di dapatkan adalah mitra menguasai aplikasi tersebut sekitar $80 \%$. Nilai persentase tersebut menyiratkan bahwa mitra mampu mengoperasikan aplikasi olx dan tokopedia.

Tabel 4. Nilai kualifikasi

\begin{tabular}{|c|c|c|c|c|c|}
\hline \multirow{3}{*}{ No } & \multirow{3}{*}{ Evaluasi } & \multicolumn{4}{|c|}{ Penilaian } \\
\hline & & SKB & KB & B & SB \\
\hline & & 1 & 2 & 3 & 4 \\
\hline 1 & $\begin{array}{lr}\text { Mitra } & \text { mampu } \\
\text { menggunakan } & \text { dan } \\
\text { membuat } & \text { account } \\
\text { email } & \\
\end{array}$ & & & & \\
\hline 2 & $\begin{array}{l}\text { Mitra mampu } \\
\text { mengakses web olx } \\
\text { dan tokopedia dengan } \\
\text { baik }\end{array}$ & & & & \\
\hline 3 & \begin{tabular}{lrr} 
Mitra & \multicolumn{2}{r}{ mampu } \\
membuat & /mendaftar \\
$\begin{array}{l}\text { account } \\
\text { tokopedia }\end{array}$ & olx & atau \\
\end{tabular} & & & & \\
\hline 4 & $\begin{array}{lr}\text { Mitra mengetahui } \\
\text { fitur-fitur } & \text { yang } \\
\text { disediakan oleh olx } \\
\text { dan tokopedia }\end{array}$ & & & & \\
\hline 5 & $\begin{array}{ll}\text { Mitra } & \text { mampu } \\
\text { menginputkan produk } \\
\text { dengan menggunakan } \\
\text { fasilitas dari Olx }\end{array}$ & & & & \\
\hline 6 & $\begin{array}{ll}\text { Mitra } & \text { mampu } \\
\text { menginputkan produk } \\
\text { dengan menggunakan } \\
\text { fasillitas dari tokopedia }\end{array}$ & & & & \\
\hline 7 & $\begin{array}{l}\text { Mitra mampu } \\
\text { melakukan edit produk } \\
\text { di olx dan tokopedia }\end{array}$ & & & & \\
\hline 8 & $\begin{array}{lr}\text { Mitra } & \text { mampu } \\
\text { melakukan } & \text { hapus } \\
\text { produk pada olx dan } \\
\text { tokopedia }\end{array}$ & & & & \\
\hline
\end{tabular}




\begin{tabular}{|c|c|c|c|c|c|}
\hline 9 & $\begin{array}{l}\text { Mitra mampu untuk } \\
\text { melihat produk mitra } \\
\text { yang dijual di olx dan } \\
\text { tokopedia, apakah } \\
\text { sesuai dengan hasil } \\
\text { inputannya. }\end{array}$ & & & & \\
\hline 10 & $\begin{array}{lr}\text { Mitra } & \text { mampu } \\
\text { menangani } & \text { dalam } \\
\text { transaksi } & \text { penjualan } \\
\text { dengan tokopedia }\end{array}$ & & & & \\
\hline & Total Nilai & 0 & 2 & 18 & 12 \\
\hline & $\begin{array}{l}\text { tal Nilai Keseluruhan } \\
\text { (TNK) }\end{array}$ & \multicolumn{4}{|c|}{32} \\
\hline & $\begin{array}{l}\text { sentase Kemampuan = } \\
(\mathrm{TNK} / 40) * 100\end{array}$ & \multicolumn{4}{|c|}{80} \\
\hline
\end{tabular}

\section{SIMPULAN}

Kesimpulan dari hasil pelaksanaan pengadian masyarakat adalah:

1. Peserta kegiatan pengabdian masyarakat telah memiliki pengetahuan dan memahami mengenai toko online dan pemanfaataanya pada pemasaran secara online pada toko online Tokopedia dan olx.

2. Peserta kegiatan mampu mengelola akun toko online pada Tokopedia dan olx, yaitu menambahkan atau melakukan unggahan deskripsi toko, deskripsi produk dan unggah foto produk dari UKM Saka Gemilang.

3. Evaluasi dilakukan dengan cara penukuran kemampuan mitra dengan mengikuti sepuluh scenario penilaian. Hasil yang didapatkan mitra memiliki kemampuan penguasaan aplikasi sebesar $80 \%$.

Kegiatan berikutnya yang dapat digunakan sebagai perbaikan pada pelaksanaan pengabdian masyarakat adalah adanya pelatihan pengenalan dan pemanfaatan akun toko online lainnya. Durasi pelatihan pada peserta yang lebih maksimal dan proses pelatihan yang lebih optimal.

\section{UCAPAN TERIMA KASIH}

Dalam penyusunan jurnal pengabdian ini, penulis banyak memperoleh petunjuk dan bimbingan dari berbagai pihak. Sehubungan dengan hal tersebut pada kesempatan ini penulis menyampaikan ucapan terima kasih yang pertama pada rektor dan Institusi Akademik yaitu Institut Teknologi dan Bisnis STIKOM Bali. Kedua ucapan terimakasih disampaikan kepada Fakultas Informatika dan Komputer Institut Teknologi dan Bisnis STIKOM Bali beserta jajaran structural serta kolega yang telah memberikan kesempatan untuk melakukan kegiatan pengabdian masyarakat. Terimakasih juga disampaiakan kepada semua pihak yang selalu memberikan dukungan secara langsung dan tidak langsung dalam penyelesaian jurnal pengabdian ini.

\section{DAFTAR PUSTAKA}

ChaffeyDave, \& MayerRichard. (2009). Internet Marketing: Strategy, Implementation and Practice. Prentice Hall/Financial Times

David, Fred R. (2010). Manajemen Strategis : Konsep-konsep. Edisi ke12.PT.Indeks Kelompok Gramedia, Jakarta.

Dehkordi, Goodarz Javadian; Rezvani, Samin; Rahman, Muhammad Sabbir;Nahid,Firoozeh Fouladivanda Neda; Jouya, Samaneh Faramarzi. (2012). A Conceptual Study on EMarketing and Its Operation on Firm's Promotion and Understanding Customer's Response. Canadian Center of Science and Education. Canada.

Florentina, Marsella. (2009). Analisa dan perancangan E-Marketing pada Omega optik. Binus University. Jakarta.

GaryArmstrong, WongVeronica, Philip Kotler, \& John Saunders. (2008). Principles of Marketing. Pearson Education Limited.

Hoffman, Douglas., Bateson, John (2006). Service Marketing : Concepts, , \& Cases. (3rd edirion). United States of America : Thomson South Western.

Rudy. (2008). Perancangan E-Marketing pada PT. JEAH nutuk Memenangkan Persaingan Usaha. 
WIDYABHAKTI

JURNAL ILMIAH POPULER 2(3): 13-20

Comtech. Vol 1 No. 2 Desember 2010:477-492.

Strauss, Judy., Frost, Raymond. (2009). EMarketing.(5th edition). New Jersey : Pearson Prentice Hall. 